\title{
The Impact of All-Inclusive System on Hotels Profits: An Applied Study to Five-Star Hotels in Hurghada City
}

Ashraf Hammad Abdel Moneim Hisham Ezzat Saad Gad Mohamed Sheded Hassan Fayoum University, Faculty of Tourism and hotels

\begin{abstract}
The main aim of this study is to explore the effect of an all-inclusive system adoption on the profitability of Hurghada five-star hotels. The current study adopted a quantitative approach using the questionnaire as a tool for data collection to test the study hypotheses and achieve its aim and objectives. The questionnaire form was distributed over 276 managers from the targeted 23 five-star hotel in Hurghada, and only (200) forms were used in this research. The results revealed that the majority of the hotels use a combination of soft \&ultra-accommodation and $47 \%$ of the respondents believe that the system is optimal also. There was a significant relationship between the All-Inclusive System (AIS) adoption and the cost management as an essential indicator of profitability, while the effect of AIS adoption on occupancy percentage was not significant. The main contribution of this research is to consider different measures of hotel profitability and to explore the impact of AIS adoption on it. This study is considered one of the fewest attempts to research hotel profitability in Egypt.
\end{abstract}

Keywords: All-inclusive system, AIS, Resorts, accommodation types, Hospitality Industry, Profitability, Financial Structure

\section{Introduction}

Krasnoperova et al., (2016) agreed with Rouby, (1986) that the topic of all-inclusive system has become an important one in the hotels industry world with its different kinds and sizes as the rationale of this system focuses on the tourist himself and saving suitable resistance places and how to meet his needs and desires as well as focusing on the continuous enhancement in all aspects of hotel work in spite of its effect on hotel performance.

Five-star hotels sector in Hurghada is considered one of the live and active service sectors and a source of national income. This sector has been developed fast because of the increasing development in the tourism sector as the number of five-star hotels has been increased as it reached (23) hotels in 2018 (Egyptian Hotel Association, 2018).

Undoubtedly, the adoption of the principles of an all-inclusive system can reinforce the quality of hotel services which should meet needs and expectations of tourists either locally or regionally (Bazazo, 2010 ; Richard \& Cleveland, 2016).

The development of an all-inclusive system gives a chance to organizers of tourist programs to urge tourists and all visitors to select those kinds of hotels. According to this development in tourists selections and tourist services, the tourist companies will be developed to meet those needs fast and the role of intervening companies between the high administration and consumers service will be fainted or disappeared (Abdel Wahab, 1996 ; Zahra, 2012 ; Tavares \& Kozak, 2015).

Mutisya (2010) and Emam, (2012) stated that all-inclusive system (pre-paid service) includes room reservation as well as three meals (breakfast - lunch - dinner) as well as snacks, soft allinclusive or hard all-inclusive. As the sector of five-star hotels in Hurghada is considered an active and live service one, therefore this study is an experimental study of all-inclusive system in Hurghada and focusing on its merits and demerits in order to solve them. 


\section{The Problem of the Study}

There are various researches in Europe, U.S.A, countries that studied AIS system and its types advantages and disadvantages (Çelebi, Kahraman, \& Daugli, 2004 ; Çiftçi, Düzakin, \& Önal, 2007; Wielenga \& Postma, 2015 ; Bilgili et al., 2016). There are few studies special in Egypt searched in the effect of an all-inclusive accommodation system on the revenue (costs and profitability). This study seeks to know the effect of an all-inclusive accommodation system on the revenue of five-star hotels in Hurghada.

Egypt has faced numerous challenges since 2011 including: low foreign investments, high debt rate, budget shortage, increased unemployment rate, high poverty and low standard of living (Abdou and Zaazou, 2013). The country suffered a sharp decline in national income and foreign currency earnings as a result of witnessing periods of demand downturn for the tourism and hotel industry. The instability in Egypt reduced its appeal to international tourists and limiting receipts and hence, funds available for investment. During the Arab Spring in 2011, the occupancy levels fall by $30 \%$ in Cairo and the resorts of Sharm El-Sheikh and Hurghada also suffered. The political turbulence led to a decline in tourist arrivals by nearly a third from 14 million in 2011 to 9.5 million World Economic Forum (WEF) (2015).WEF showed that Egypt is $83^{\text {rd }}$ out of 141 countries in the global ranking and the 10th in the Middle East and North Africa in the list of world's attractive destinations. The tourism industry contributes to Egyptian GDP with 5.7\% of total GDP and employs $5.1 \%$ of total employment.

Above reasons made, the Ministry of Tourism, started with many initiatives to encourage the domestic tourism, such as "know your country" initiative and "Egypt in our hearts", the majority of targeted hotels from domestic tourism operate with the all-inclusive system although, this domestic tourism caused moving to the hotels occupancy, the hotels managers and owners of these hotels have begun to complain about the high cost of domestic tourism, this motivates the researcher to investigate this issue and its effect on hotels profitability (from the researchers' professional experience).

\section{Aim and Objectives of the study}

Due to the lack of information about the effect of an all-inclusive system on the profitability of Hurghada five-star hotels, this study set main aim that:

- Exploring the effect of an all-inclusive system adoption on Hurghada five-star hotels' profitability.

The researcher sets the following objectives to achieve the aim of the study:

* Identifying the applied types of AIS in Hurghada five-star hotels.

* Identifying the best type/s of the AIS from the managers' point of view.

* Highlighting the importance of the all-inclusive system.

* Exploring the impact of the AIS on the hotels' cost management.

* Exploring the impact of the AIS on the hotels' occupancy.

\section{Limitation of the study}

The main objective of this study was explore the effect of an all-inclusive system on Hurghada five-star hotels profitability. Due to the many obstacles that faced the researcher, including the following:

Objective limitation: The current study aims to exploring the effect of an all-inclusive system on Hurghada five-star hotels profitability. Accordingly, monitors, the researcher choose two of 
them: cost management and occupancy rate as they are the most important profitability monitors as the researcher could not obtain direct profitability reports in hotel for the following reasons:

1- Difficulty in accessing data and information related to financial aspects, especially with respect to hotel revenues Sample study. Since these data are considered highly confidential.

2- The severity of the sensitivity of the subject of the study as it relates to the financial aspects and profits

3- Lack of actual cooperation by a number of hotels and their managers to facilitate the procedures for implementing the field part of this study

\section{Review of Literature}

\section{A Brief History about the all-inclusive system (AIS)}

The original all-inclusive concept was first introduced in holiday camps in Britain during the 1930s and the initial elements of the all-inclusive offer were: good beverages and fare, safe and comfortable accommodations, caring staff, and plenty of accessible activities (Issa \& Jayawardena,2003; Rayna \& Striukova,2009).

Another story for the "All-inclusive" as a system in hotels came out in the 1960s; and today it is being used in a fairly large scale all over the world. In general, the system is utilized by developing countries so as to increase their voice further in hotels activities. This system consists of a package in which the price is fixed and includes food, beverages, accommodation, and other amenities. Though it is used on a large scale in the world, there are some negative views about this system (Ciftci et al., 2007; Condratov, 2014).

All-Inclusive holiday concept was developed in the 1990s to respond to a growing demand from guests for a holiday which was priced to include all food, accommodation, and activities for the duration of stay. First choice holidays was the first package holiday operator introduce the allinclusive holiday into the mainstream market with the introduction of a wide range of allInclusive deals to popular summer Mediterranean destinations (Swarbrooke \& Horner,1999).

All-inclusive holidays have been a strong growth sector within the total holiday market since 1997. They are defined as those holidays where all travel, accommodation, food and drink, entertainment, trips or sports coaching, are paid for when booking for one established price (Mutisya, 2010).

The concept of all-inclusive programs is being used on a fairly large scale all over the world. Generally, all-inclusive programs allow the guest to receive a package of services including accommodation, food, beverages, and other services and other amenities for set pre-paid prices (Saleh et al., 2013).

All-Inclusive concept is an extension of the full board which is the practice of some hotels. These hotels charge a daily rate and include all meals, and also unlimited use of sports and social facilities of the hotel. This is a very attractive package for resort hotel, and makes accounting easier (Dix and Baird, 1992). All-Inclusive Principle as covering four to five meals a day plus entertainment and activities, representing a value not easily matched by many resorts (Reinhold, 1997).

All Inclusive System is the application of a marketing and pricing system in which all services such as breakfast, lunch, dinner, room services, local and import drinks, sport activities are covered under a fixed price package. This is a quite different application from the traditional one in which each service is priced under different packages (Onal et al.,2007). 
The all-inclusive concept goes much further and covers practically everything which the resort has to offer, including all drinks, taxes, transfers and sports from airport to hotel, with tipping being prohibited. Some resorts` rates also include airport transfers, snacks, scuba diving, weddings, horseback riding, spa treatments, golf and more. As almost everything is paid before leaving home, (Issa \& Jayawardena, 2003). Therefore, all the members of a family traveling within this system are able to spend their vacation without any budget squeeze. Hence, all of the vacation difficulties and complaints are automatically reduced by using this system (Onal et al.,2007).

\section{Advantages and Disadvantages of All-Inclusive System}

The positive and negative aspects of the all-inclusive system There seems to be a considerable discussion all around the world concerning the sectors within the all-inclusive framework and their effects on regional economies moreover, the overall positive and negative outcomes of this particular system have been discussed in a wider platform (Çiftçi et al., 2007).

As per Bilgili et al., (2016); Condratov, (2014) The positive aspects of the all-inclusive system in general, are summarized below :

- It eliminates the unexpected expenditures faced by guests during their vacation.

- It enables guests to spend their vacation in a foreign country without being deceived and under security.

- It increases the hotels occupancy rate.

- It can affect the employment level of the country positively.

- It assists travel agencies and tour operators in marketing hotels with relative ease.

- Since the system increases the circulation of guests it may be a crucial foreign currency resource for related countries.

- The hotels applying the all-inclusive system are eligible for extending their tourism seasons between 15 to 30 days.

- It is only possible for large-scale hotels buying their food, drinks and other needs in total and huge amounts to drop costs being granted a rebate.

- The level of profit is affected positively for the hotels at issue due to the lower cost of inputs in the high seasons of the all-inclusive system.

- Guests' staying at the hotel all day long causes activity and accordingly sales for the other goods be outside the package increases too.

- This system relieves families greatly by providing different activities for children.

On the other hand Pelit et al., (2011) and Krasnoperova et al., (2016) and reported that the main disadvantage of this type of accommodation is that the person can't get to know peculiarities of the country, its people and culture.

The negative aspects of the all-inclusive system are summarized below (Çelebi et al., 2004; Çiftçi et al., 2007; Wielenga \& Postma, 2015; Bilgili et al., 2016) :

- The guests may not have exact information on what is included and what is excluded in the fixed price package in the application of the all-inclusive system.

- The guests staying in the hotels that apply the all-inclusive system are unlikely to go to different places in the city for shopping.

- The guests generally tend to spend all their time at the hotel and thus cannot get enough information about the historical background and social structure of the region. 
- The guests, who spend most of their time within the boundaries of the hotel, are likely to assume that any failure occurring within the hotel could be met all around the city as well.

- The hotels applying this system are likely to reduce their service quality level to increase profitability.

- The system may give rise to unfair competition. As a result, the preference for the hotels that care for quality could be reduced.

- In most of the accommodation hotels, the staff may treat the guests badly and may accuse them of being responsible for their low salary and heavy working conditions.

\section{The Financial Implication of All-Inclusive System in the Hotel Industry}

The majority of the hotels sector is complaining about this system. While tour operators stress the low level of profitability, hotel owners and managers think that they lose their sales and provide free services. On the other hand, employees consider themselves to be working longer hours but getting lower wages while tradesmen of the region complain about selling few products due to the application of the all-inclusive system. As for the customers, they complain about waiting long hours for the service and getting lower quality of the services (Onal et al., 2007) Ozdemir et al., (2011) resulted in his study that the effects of the all-inclusive system on the costs of the accommodation enterprises are the most significant cost item is observed to be "AIS increases waste" (average: 4.48). This is followed by "AIS increases maintenance \& repair costs" (average: 3.66), "AIS increases depreciation costs" (average: 3.58), "AIS increases energy costs" (average: 3.30), "AIS increases costs of the enterprises" (average: 3.10), "AIS increases production costs" (average: 3.06), and "AIS increases procurement costs" (average: 3.05), respectively. $57 \%$ of the respondents assert that AIS increases the costs of the enterprises, while $53 \%$ say that the AIS increases employment and $40 \%$ think this system increases staff costs.

In such a case, the system may not provide sufficient benefit (or gain) for the country where tourists go for vacation. Furthermore, restaurants and other entertainment centres operating in the holiday camp complain that the all-inclusive system prevents the customers who would otherwise prefer them (Ciftci et al., 2007).

One of the important factors regarding adopting All Inclusive System is the dimension of the tourist unities. It is possible to be applied, usually, only within the unities of big dimensions, because the significant discounts in buying the food, drinks and other products are offered for great quantities (Condratov, 2014).

An observation of the all-inclusive system relates to profitability, costs, and waste. In their studies carried out in Antalya, Uner et al., (2007) and Unguren et al., (2009) assert that the AIS increases occupancy rates in accommodation enterprises. Uner et al., (2007) argue in their empirical study that the AIS enhance the competitiveness of the accommodation enterprises, enabling them to increase room fees, and increase their profitability.

Demir et al., (2001) also claim that the AIS increases the occupancy rate. Further, in another study carried out in Antalya, Demir, (2004) asserts that the AIS increases the revenue of the enterprises. Conversely, Demir, (2004) claim in their more recent empirical study that the AIS reduces the profits of the enterprises, while Demir et al., (2001) emphasize that enterprises implementing the AIS have a lower profit than enterprises which do not implement it.

\section{Profitability concept}

The capability to absolutely formulate and put in force a coherent method is crucial for success in hospitality enterprise, and earlier literature focused on resorts' company approach to achieve a 
higher season profitability. The strategic decisions regarding location (Yang, Luo and Law, 2014), brand chain affiliation, independently or franchised operating (Perrigot et al., 2009) , internationalization and hotel age (Xiao, O’Neill and Mattila, 2012) impact on performance.

There are several prior studies investigating the influence of size on hotel financial outcomes (Assaf and Cvelbar, 2010). Many studies (Chen \& Tseng, 2005; Barros \& Mascarenhas, 2005) demonstrated a positive relationship between size and hotel profitability. This positive relationship is assured by (Kim et al., 2013) for gross operating profit and occupancy rate (Banker et al., 2005). (Claver et al., 2006) verified that larger hotels attain higher levels of performance, as large firm size usually permits to incur in economies of scope or economies of scale resulting in lower operational costs (Santoro, 2015). They claimed that large and mediumsized hotels are well performing than small ones. Pine \& Phillips, (2005) also proved these findings employing Revenue Per Available Room (RevPAR) as a profitability measure for hotels clustered by stars rating and ownership form. On the contrary, a large-sized hotel could be low in quality, as it offers more standardized products and services at lower prices. In this situation, hotel size may have a negative impact on profitability, as evidenced by Chen, (2009) and Ben Aissa \& Goaied, (2016). Based on the majority of prior studies, this study examines the impact of AIS on Hurghada hotels and it suppose that it positively affects profitability.

The international attractiveness of hotels is considered another crucial determinant of hotel profitability, but limited literature studied this variable empirically. For example, Lee, (2008) and Tang \& Jang, (2009) examined the impact of internationalization on hotel profit and they found that publicly traded US hotels may take advantage of an international customer orientation. Internationalization enables firms to benefit from the acquisition of international knowledge, experience and operational flexibility that enhance competitive positioning within international markets (Lee et al., 2014). On the contrary, Graves \& Shan, (2014) demonstrated that internationalization of Australian SMEs has a negative influence on Return On Assets (ROA). Based on the majority of prior studies, I investigate the impact of internationalization (INTER) on hotel profitability and assume that internationalized hotels show a higher profitability than non-internationalized hotels.

\section{Performance measures}

Cost targeting, ROE, ROA, occupancy percentage, stock return, productivity and profit per unit of production have been widely considered measures of profitability in the hospitality literature (Turner \& Guilding, 2011 ; Xiao et al., 2012). Although the definition of profitability varies among studies, (cost management) as alternative measures of hotel profitability (i.e. dependent variables) in line with previous literature (Ozdemir et al., 2011). AIS application is the first independent variable included in this study analysis. In addition, the Occupancy Percentage (OP) is a commonly used measure of performance in the hotel industry (Sun and Lu, 2005), considering the dislike of the Egyptian hotel managers to give any information on profitability. $\mathrm{OP}$ is the percentage of occupancy and it expresses the relationship between the number of rooms occupied and the total number of hotel rooms that can be occupied (available rooms). Finally, hotel performance is measured in terms of gross operating profit as a profitability measure that reflects the manager's effectiveness (Dev et al., 2009).

\section{Determinants of profitability}

As potential determinants of hotel profitability, this study considered one independent variable (AIS Application) and control variables (location, Gender, Experience, Education). Regarding 
profitability variables, this study explored the impact of (AIS Application) and cost targeting management. In hospitality literature, several studies focused on hotels' corporate strategy as the set of organizational and strategic solutions through which the hotel firm operates to achieve a higher performance (Parte-Esteban and Ferrer Garcia, 2014).

\section{Methodology}

The current study adopted a quantitative method using the questionnaire as a tool for data collection to test the study hypotheses and achieve its objectives. The methodology designed for the current study, was guided by the primary study hypotheses and the subsequent study objectives. The focus of the study was to explore the effect of all-inclusive system on hotels' profitability of five-star hotels therefore; the researcher found that the quantitative method is an appropriate method to give practical significance to this study. In this regard, the current study adopted the quantitative tool, which included a mixture between adapted and developed questionnaire.

\section{Population and Sampling}

The study targeted the five stars' hotels in Hurghada city counted (23) hotels detailed in below table (1) as per the Egyptian Hotel Association data on the updated website.

Table 1 : Hurghada five stars hotels

\begin{tabular}{|c|l|}
\hline SR & \multicolumn{1}{|c|}{ Hotel Name } \\
\hline 1 & Blue Lagoon Hurghada Resort \\
\hline 2 & Citadel Azur Sahl Hasheesh Resort \\
\hline 3 & Continental Resort Hurghada \\
\hline 4 & Dana Beach Resort \\
\hline 5 & Garden Beach Resort \\
\hline 6 & Grand Makadi Hotel \\
\hline 7 & Hilton Hurghada Plaza \\
\hline 8 & Hilton Hurghada Resort \\
\hline 9 & Holidays Resort \\
\hline 10 & Hurghada Marriott Beach Resort \\
\hline 11 & Jaz Makadi Star Resort \& Spa \\
\hline 12 & Makadi Palace Hotel \\
\hline 13 & Mamlouk Palace Resort \\
\hline 14 & Prima Life Makadi Hotel \\
\hline 15 & Pyramisa Sahl Hashish Hotel \\
\hline 16 & Royal Makadi Resort \\
\hline 17 & Serenity Makadi Heights \\
\hline 18 & Sonesta Pharaoh Beach Resort \\
\hline
\end{tabular}


International Journal of Heritage, Tourism and Hospitality Vol. (13), No. (1), March, 2019

By: Faculty of Tourism and Hotels, Fayoum University

\begin{tabular}{|l|l|}
\hline 19 & Steigenberger Al Dau Beach Hotel \\
\hline 20 & The Desert Rose Resort \\
\hline 21 & The Oberoi Sahl Hasheesh Resort \\
\hline 22 & Tia Heights Makadi Bay \\
\hline 23 & Titanic Beach Spa \& Aqua Park \\
\hline
\end{tabular}

Source: (Egyptian Hotel Association)

The prime and main reason for choosing this category is that the majority of five-star hotels applying all-inclusive programs and these hotels follow international chains and local management.

In this study, a purposive sampling technique (also known as convenience sampling) was used to select hotel managers of hotels listed in table (2) while the researcher choose five departments in listed hotels in table (2), and this departments is, top management department, financial department, rooms division department (front office, reservation and revenue sections), food \& beverage department and sales \& marketing department, then the researcher choose from each department the department manager and his assistant to be the purposive sample of this study.

Above mentioned sample been choosing as a purposive sample as these departments' managers is partially or totally involved with the cost and profitability of these hotels.

\section{Data Collection Tool}

The study was conducted as a survey study which is the most popular (quantitative) study design in social science. Survey study designs are quite flexible and can therefore, appear in a variety of forms, but all are characterized by the collection of data using standard questionnaire forms administered by telephone or face to face, by postal or increasingly by using web-based and email forms (Muijs, 2010).

The researcher use both hard and online copy questionnaire form with twenty-six closed-ended questions and make a site visit to collect data from the targeted sample, (70) form been collected from the hard copy distribution also, soft copy on Google drive been shared with the managers couldn't get them to get their responses, (150) for been collected from the online sharing questionnaire with total (220) collected questionnaires.

The most common forms of secondary data sources are books, academic journal articles, official governmental statistics, internet data, and other publications. All secondary data sources are illustrated in the previous chapter "Review of Literature".

\section{Validity and Reliability}

The questionnaire was initially pre-tested for its validity with 20 managers in Hurghada hotels. The researcher used person correlation test to determine from the internal consistency for all statements and ensure that it valid to analyze.

In addition, the questionnaire sends to professors at hotels studies department at the faculty of tourism and hotels, Fayoum University to get feedback regarding the clarity of the instructions and accuracy of the questions in the instrument. Comments and suggestions obtained from the pre-test were used for rewording the instructions and layouts of the questionnaire.

Results in the table (2) showed that there is a positive significant correlation on 0.05 degree between questionnaire statements, with 0.71 for questionnaire' dimensions.

Table 2: Internal consistency for investigated questionnaire 
International Journal of Heritage, Tourism and Hospitality Vol. (13), No. (1), March, 2019

By: Faculty of Tourism and Hotels, Fayoum University

\begin{tabular}{|l|l|c|c|}
\hline \multicolumn{1}{|c|}{ Dimension } & \multicolumn{1}{c|}{ Sub-dimensions } & Corr. & P. Value \\
\hline \multirow{2}{*}{$\begin{array}{l}\text { Questionnaire } \\
\text { Statements }\end{array}$} & Reasons for choosing all-inclusive & 0.69 & 0.037 \\
\cline { 2 - 4 } & The impact on the hotel's own costs & 0.73 & 0.000 \\
\cline { 2 - 4 } & The impact on the hotel 's profitability & 0.70 & 0.004 \\
\hline \multicolumn{2}{|c|}{ Total } & 0.71 & --- \\
\hline
\end{tabular}

\section{Hypotheses of the study}

Based on the researchers' reading about the subject of the hotel all-inclusive system, it could be set some hypotheses. These hypotheses emanated from the objectives of the study and its importance.

Hypotheses of the study were as follows:

Hypothesis 1: There is a significant difference among the hotel sample according to the AIS Adoption.

Hypothesis 2: There is a significant difference among the hotel sample according to the AIS importance.

Hypothesis 3: There is a significant relationship between the all-inclusive system adoption variable and the hotel profitability:

Hypothesis 3.1: There is a significant relationship between the all-inclusive system adoption variable and hotel cost management.

Hypothesis 3.2: There is a significant relationship between the all-inclusive system adoption variable and the hotel occupancy rate.

\section{Results and Discussion}

The questionnaire form was distributed over (276) manager and assistant from the targeted (23) five-star hotel in Hurghada, and only (220) respondents completed the form with response rate of (79\%) of total forms distributed, after eliminating the invalid forms, only (200) forms were included in this study.

\section{Demographics and Description of Respondents}

For all scales, Cronbach Alpha correlation coefficient was calculated to determine the internal consistency of the scale. The computation of Cronbach alpha is based on the number of items on the questionnaire and the ratio of the average inter-item covariance to the average item variance. The Reliability coefficient of 0.50 or higher is considered "acceptable" in most social science research situations. The Cronbach Alpha reliability was computed and the tests showed that the reliability coefficients for all the instruments were above 0.70 which indicates that the instrument is reliable for being used.

For this study, Cronbach alpha for all variables survey instruments presented in table (3) as follows:

Table 3: Measuring reliability

\begin{tabular}{|l|c|c|}
\hline \multicolumn{1}{|c|}{ Items } & Number of Statements & Alpha Cronbach's \\
\hline Importance of AIS adoption & 7 & 0.68 \\
\hline Cost management & 10 & 0.81 \\
\hline
\end{tabular}

The previous table indicates that Alpha Cronbach's is greater than or equals $0.60=$ "0.68", and "0.81" which shows that the internal harmony in the questionnaire and correlation coefficient between every section of the questionnaire and other sections is extremely reasonable. Therefore, 
the researcher has been ensured that all statements in questionnaire are reliable and suitable to analyze (Hair et al., 1995).

\section{Respondents' profile analysis}

Before analysing data collected from questionnaires, it was checked and verified for accuracy of data entry. This part shows the results of the study by using ideal statistical tests that achieve the main aim of the study and its objectives. It also includes the discussion on obtained results. The questionnaire form is designed in a way to investigate hotels' managers to determine the impact of all-inclusive system on the profitability of five-star hotels in Hurghada city.

The questionnaire is divided into three sections; personal data, subjected questions and statements. The two section "statements" designed to identify the importance of the all-inclusive system and the cost management. In the following, each of these sections will analyze and discussed.

The questionnaire form was distributed to (276) manager and assistant from the targeted (23) five-star hotel in Hurghada, and only (220) respondents completed the form with response rate of (79\%) of total forms distributed, after eliminating the invalid forms, only (200) forms were included in this study.

\section{The questionnaire (Part one): demographic data}

This section includes five personal data (gender, age, level of education, department, and finally years of experiences. These data aimed to recognize the demographic data of hotels' managers. The results are shown in table (4).

Table 4: Demographic data of respondents

\begin{tabular}{|c|c|c|c|c|}
\hline \multirow[t]{2}{*}{ Demographic Data } & \multirow[t]{2}{*}{ Attribute } & \multicolumn{2}{|c|}{ Statistics } & \multirow[b]{2}{*}{ Rank } \\
\hline & & Freq. & $\%$ & \\
\hline \multirow[t]{2}{*}{ Gender } & Male & 200 & 100 & 1 \\
\hline & Female & 0 & 0 & - \\
\hline \multicolumn{2}{|r|}{ Total } & 200 & \multicolumn{2}{|c|}{$100 \%$} \\
\hline \multirow[t]{3}{*}{ Age } & From $31-40$ years & 92 & 46.0 & 1 \\
\hline & From $41-50$ years & 87 & 43.5 & 2 \\
\hline & From $51-60$ years & 21 & 10.5 & 3 \\
\hline \multicolumn{2}{|r|}{ Total } & 200 & \multicolumn{2}{|c|}{$100 \%$} \\
\hline \multirow[t]{2}{*}{ Educational level } & University Degree & 192 & 96.0 & 1 \\
\hline & Postgraduate Degree & 8 & 4.0 & 2 \\
\hline \multicolumn{2}{|r|}{ Total } & 200 & \multicolumn{2}{|c|}{$100 \%$} \\
\hline \multirow{5}{*}{ - Department } & Top Management & 30 & 15.0 & 5 \\
\hline & Financial Controller & 35 & 17.5 & 2 \\
\hline & Rooms Division & 71 & 35.5 & 1 \\
\hline & Food \& Beverage & 33 & 16.5 & 3 \\
\hline & Sales and Marketing & 31 & 15.5 & 4 \\
\hline & Total & 200 & \multicolumn{2}{|c|}{$100 \%$} \\
\hline \multirow[t]{4}{*}{ Years of experience } & From $1-5$ years & 22 & 11.1 & 3 \\
\hline & From $5-10$ years & 11 & 5.5 & 4 \\
\hline & From $10-15$ years & 106 & 52.8 & 1 \\
\hline & More than 15years & 61 & 30.7 & 2 \\
\hline
\end{tabular}


International Journal of Heritage, Tourism and Hospitality Vol. (13), No. (1), March, 2019 By: Faculty of Tourism and Hotels, Fayoum University

\begin{tabular}{|l|l|c|c|c|}
\hline \multicolumn{2}{|l|}{ Total } & 200 & \multicolumn{2}{c|}{$100 \%$} \\
\hline \multirow{3}{*}{ Hotel average occupancy } & $70 \%$ & 9 & 4.5 & 7 \\
\cline { 2 - 5 } & $80 \%$ & 27 & 13.5 & 4 \\
\cline { 2 - 5 } & $85 \%$ & 37 & 18.5 & 2 \\
\cline { 2 - 5 } & $90 \%$ & 42 & 21 & 1 \\
\cline { 2 - 5 } & $94 \%$ & 9 & 4.5 & 8 \\
\cline { 2 - 5 } & $95 \%$ & 37 & 18.5 & 3 \\
\cline { 2 - 5 } & $98 \%$ & 13 & 6.5 & 6 \\
\cline { 2 - 5 } & $99 \%$ & 9 & 4.5 & 9 \\
\cline { 2 - 5 } & $100 \%$ & 17 & 8.5 & 5 \\
\hline
\end{tabular}

As it can be observed from the previous table (5) that all respondents (100\%) were male, and there was no female in the manager's position. The results refer to that the majority of managers in the investigated hotel were male.

According to age group in, among the 200 respondents, $46 \%$ fell into the age group 31-40 years; this was followed by age group 41-50 years by $43.5 \%$. The age group from 51 to 60 years were the smallest group and presented by $10.5 \%$. This result indicated that the majority of managers were from youth age group.

With respect to the educational level variable, a high proportion of the tested sample (96\%) has a university educational degree. Managers with postgraduate degree was the smallest group and presented by (4\%). This result clarified that getting postgraduate degree is not a condition for promoting to managerial level in investigated hotels.

The results also showed that the high proportion of the tested sample $(35.5 \%)$ worked in rooms division. While $17.5 \%$ was work as financial controller, this followed by food and beverage division managers with $16.5 \%$, then sales and marketing manager with $15.5 \%$. Managers in top management were the smallest group and presented by $15 \%$. These result back to the difficulty in investigating top managers such as; general managers due to they are always busy in meetings.

The results also showed that years of experience of the majority of the managers $(52.8 \%)$ were less from 10 to 15 years, while $30.7 \%$ wasmore than 15 years, this followed by managers with 1-5 years of experiences. Managers with years of experience from 5 to 10 were the smallest group and presented by $5.5 \%$.

The results show that the hotel occupancy give results for average occupancy between $70 \%$ and $100 \%$, while the largest number of responses was 42 respond with $90 \%$ occupancy, then 37 responses respond with $95 \%$ occupancy, another 37 responses respond with $85 \%$ occupancy, then 27 responses respond with $80 \%$ occupancy, and rest of responses as shown was respond with $100 \%, 98 \%, 99 \%, 98 \%$ and $70 \%$,

Above table present that the total average of responses was $90.11 \%$ average occupancy, meanwhile high average occupancy under the umbrella of AIS.

\section{The average length of stay for guests in the targeted hotel sample}

The purpose of this question is to know average length of stay for guests in targeted hotels. Table (5) shows the answer of this question.

Table 5: Average length of stay

\begin{tabular}{|l|c|c|c|}
\hline \multicolumn{1}{|c|}{ Variables } & Frequency & Percentage (\%) & Rank \\
\hline From 1 to 3 nights & 30 & 15.0 & 2 \\
\hline From 4-7 nights & 161 & 80.5 & 1 \\
\hline
\end{tabular}


International Journal of Heritage, Tourism and Hospitality Vol. (13), No. (1), March, 2019

By: Faculty of Tourism and Hotels, Fayoum University

\begin{tabular}{|c|c|c|c|}
\hline From 8 to 14 nights & 9 & 4.5 & 3 \\
\hline Total & 200 & $100 \%$ & - \\
\hline
\end{tabular}

Results in table (6) indicated that the majority of guests (80.5\%) of stayed in the targeted hotels from 4 to 7 nights. Meanwhile $15 \%$ of guests stayed from one to three nights. Finally, a guest with long accommodation from 8 to 14 was the smallest group and presented by $4.5 \%$.

\section{The questionnaire (Part two):}

This section includes three main questions. The purpose of this question is to recognize the type of all-inclusive system (AIS) used in investigated hotels, and determine the best types of allinclusive system (AIS) from managers' point of view, then finally know average length of stay for guests in investigated hotels. The results are shown in the following tables and figures.

The best type of all-inclusive system (AIS)

The purpose of this question is to determine the best types of all-inclusive system (AIS) from manager's point of view. Table (6) shows the answer to this question.

Table 6): The best type of AIS used in hotels

\begin{tabular}{|c|c|c|c|}
\hline Variables & Frequency & Percentage (\%) & Rank \\
\hline No AIS & 18 & 9.0 & 4 \\
\hline Soft AIS & 58 & 29.0 & 2 \\
\hline Ultra AIS & 30 & 15.0 & 3 \\
\hline Both (Soft \& ultra) & 94 & 47.0 & 1 \\
\hline Total & 200 & $100 \%$ & - \\
\hline
\end{tabular}

Results in the table (7) showed that a high proportion (47\%) of the investigated managers preferred both (soft \& ultra). Meanwhile $29 \%$ of tested sample preferred soft AIS, this followed by managers that found ultra AIS is the best with $15 \%$. Finally, 9\% of investigated managers realized that no AIS is the best system.

\section{The all-inclusive system (AIS) adoption level in targeted hotels}

The purpose of this question is to recognize the type of all-inclusive system (AIS) used in investigated hotels. Table (7) shows the answer of this question.

Table 7: Type of all-inclusive system (AIS) used in hotels

\begin{tabular}{|c|c|c|c|}
\hline Variables & Frequency & Percentage (\%) & Rank \\
\hline No AIS & 4 & 2.0 & 4 \\
\hline Soft AIS & 75 & 37.5 & 2 \\
\hline Ultra AIS & 19 & 9.5 & 3 \\
\hline Both (Soft \& ultra) & 102 & 51.0 & 1 \\
\hline Total & 200 & $100 \%$ & - \\
\hline
\end{tabular}

It can be observed from the previous table (8) that a high percent (51\%) of the investigated hotels applied both (Soft \& ultra). Meanwhile $37.5 \%$ of tested sample preferred soft AIS; this followed by hotels used ultra AIS with 9.5\%. Finally, $2 \%$ of investigated hotels did not apply the allinclusive system.

\section{The questionnaire (Part three): variables analysis}

This section is divided into three main dimensions. The purpose of these dimensions is to explore the importance of the all-inclusive system, and determine the impact of the all-inclusive system 
on the hotels' costs, and then finally identify the impact of the all-inclusive system on the hotel's profitability. The results are shown in the following tables.

The importance of all-inclusive system adoption

The purpose of this dimension is to explore reasons for hotels for choosing of all-inclusive system. Table (8) shows the answer to these statements.

Table 8: The importance of AIS

\begin{tabular}{|c|c|c|c|c|c|c|}
\hline Factor & Sub-Variables & Freq. & Per.\% & Mean & S.D. & $\mathrm{R}$ \\
\hline \multirow{5}{*}{$\begin{array}{l}\text { AIS is considered as the } \\
\text { best accommodation } \\
\text { system in reducing costs. }\end{array}$} & $\begin{array}{l}\text { Strongly } \\
\text { disagree }\end{array}$ & 11 & 5.5 & \multirow{5}{*}{3.04} & \multirow{5}{*}{1.091} & \multirow{5}{*}{6} \\
\hline & Disagree & 61 & 30.5 & & & \\
\hline & Neutral & 59 & 29.5 & & & \\
\hline & Agree & 48 & 24.0 & & & \\
\hline & Strongly Agree & 21 & 10.5 & & & \\
\hline \multirow{5}{*}{$\begin{array}{l}\text { AIS is the best } \\
\text { competitive system } \\
\text { especially under fierce } \\
\text { competition with other } \\
\text { hotels. }\end{array}$} & $\begin{array}{l}\text { Strongly } \\
\text { disagree }\end{array}$ & 0 & 0 & \multirow{5}{*}{3.84} & \multirow{5}{*}{.798} & \multirow{5}{*}{4} \\
\hline & Disagree & 10 & 5.0 & & & \\
\hline & Neutral & 52 & 26.0 & & & \\
\hline & Agree & 98 & 49.0 & & & \\
\hline & Strongly Agree & 40 & 20.0 & & & \\
\hline \multirow{5}{*}{$\begin{array}{l}\text { AIS is encouraged and } \\
\text { selected by many travel } \\
\text { and tourism companies }\end{array}$} & $\begin{array}{l}\text { Strongly } \\
\text { disagree }\end{array}$ & 0 & 0 & \multirow{5}{*}{4.05} & \multirow{5}{*}{.582} & \multirow{5}{*}{3} \\
\hline & Disagree & 0 & 0 & & & \\
\hline & Neutral & 29 & 14.5 & & & \\
\hline & Agree & 132 & 66.0 & & & \\
\hline & Strongly Agree & 39 & 19.5 & & & \\
\hline \multirow[t]{5}{*}{$\begin{array}{l}\text { AIS increases the } \\
\text { rate of hotel occupancy. }\end{array}$} & $\begin{array}{l}\text { Strongly } \\
\text { disagree }\end{array}$ & 0 & 0 & \multirow{5}{*}{4.20} & \multirow{5}{*}{607} & \multirow{5}{*}{1} \\
\hline & Disagree & 0 & 0 & & & \\
\hline & Neutral & 21 & 10.5 & & & \\
\hline & Agree & 119 & 59.5 & & & \\
\hline & Strongly Agree & 60 & 30.0 & & & \\
\hline \multirow[t]{5}{*}{$\begin{array}{l}\text { AIS preferred by many } \\
\text { guests. }\end{array}$} & $\begin{array}{l}\text { Strongly } \\
\text { disagree }\end{array}$ & 0 & 0 & \multirow{5}{*}{4.15} & \multirow{5}{*}{.804} & \multirow{5}{*}{2} \\
\hline & Disagree & 10 & 5.0 & & & \\
\hline & Neutral & 22 & 11.0 & & & \\
\hline & Agree & 97 & 48.5 & & & \\
\hline & Strongly Agree & 71 & 35.5 & & & \\
\hline \multirow{5}{*}{$\begin{array}{l}\text { AIS encourages the } \\
\text { government to continue } \\
\text { working with this } \\
\text { system. }\end{array}$} & $\begin{array}{l}\text { Strongly } \\
\text { disagree }\end{array}$ & 29 & 14.5 & \multirow{5}{*}{2.90} & \multirow{5}{*}{1.037} & \multirow{5}{*}{7} \\
\hline & Disagree & 21 & 10.5 & & & \\
\hline & Neutral & 101 & 50.5 & & & \\
\hline & Agree & 39 & 19.5 & & & \\
\hline & Strongly Agree & 10 & 5.0 & & & \\
\hline
\end{tabular}


International Journal of Heritage, Tourism and Hospitality Vol. (13), No. (1), March, 2019 By: Faculty of Tourism and Hotels, Fayoum University

\begin{tabular}{|c|c|c|c|c|c|c|}
\hline \multirow{5}{*}{$\begin{array}{l}\text { AIS is considered } \\
\text { the best systems in terms } \\
\text { of prices. }\end{array}$} & $\begin{array}{l}\text { Strongly } \\
\text { disagree }\end{array}$ & 0 & 0 & \multirow{5}{*}{3.24} & \multirow{5}{*}{.757} & \multirow{5}{*}{5} \\
\hline & Disagree & 29 & 14.5 & & & \\
\hline & Neutral & 105 & 52.5 & & & \\
\hline & Agree & 56 & 28.0 & & & \\
\hline & Strongly Agree & 10 & 5.0 & & & \\
\hline \multicolumn{4}{|c|}{ Average Mean } & 3.63 & ------ & -- \\
\hline
\end{tabular}

Note: $\mathrm{R}=$ Rank, S.D. = Standard Deviation

According to the results shown in the table (10), the respondents agreed on four statements from all statements of dimension reasons for hotels for choosing of the all-inclusive system which are arranged according to their means as follows:

- The statement of "AIS increases the rate of hotel occupancy" has got the highest percentage of agreement from the respondents at (Mean=4.20).

- The statement of "AIS preferred by many guests" at (Mean=4.15). This result agreed with Issa and Jayawardena (2003) result that guests can relax without worrying about currency exchange rates, local tipping customs, running out of cash or exceeding their budget. In addition to that, all of the vacation difficulties and complaints are automatically reduced by using this system (Onal et al., 2007).

- The statement of "AIS encouraged and selected by many travel and tourism companies" at (Mean=4.05). This result agreed with that it is known that tour operators and hotels use the all-inclusive system as a selling and marketing method based on the demand of customer desires (Ciftci et al., 2007).

- The statement of "AIS is the best competitive system especially under fierce competition with other hotels" at (Mean=3.84). This result in contrast with Ciftci et al., (2007) result that the unfair competition caused by the markets in the hotels and the holiday villages, or the hypermarkets were gone through the tours for shopping should also be considered as another negative effect resulting from the application of the all-inclusive system.

Meanwhile, the responses of managers were neutral with three statements from all statements of reasons for hotels for choosing of the all-inclusive system which is arranged according to their means as follows:

- The statement of "AIS is considered the best systems in terms of prices" at (Mean=3.24).

- The statement of "AIS considered as the best accommodation system in reducing costs" at (Mean=3.04). This result in contrast with Onal et al., (2007) findings that the all-inclusive system has increased the food and beverage consumption in the hotels and these have turned out to be the most important items within the total expenditures.

- The statement of "AIS encourages the government to continue working with this system " at (Mean=2.90). In this sense, it could be noticed that, since the system increases the circulation of guests it may be a crucial foreign currency resource for related countries (Condratov, 2014).

Results in the table (8) clarified that managers agreed with statements of dimension reasons for hotels for choosing the all-inclusive system with an average mean (3.63).

\section{The impact of the all-inclusive system on the hotels' cost}

The purpose of this dimension is to identify the impact of the all-inclusive system on the hotels' costs. Table (9) shows the answer of these statements. 
International Journal of Heritage, Tourism and Hospitality Vol. (13), No. (1), March, 2019 By: Faculty of Tourism and Hotels, Fayoum University

Table 9: The impact of the AIS on the hotels' costs

\begin{tabular}{|c|c|c|c|c|c|c|}
\hline Factor & Sub-Variables & Freq. & Per. $\%$ & Mean & S.D. & $\mathrm{R}$ \\
\hline \multirow{5}{*}{$\begin{array}{l}\text { AIS causes an increase in } \\
\text { the depreciation of assets } \\
\text { and equipment in the hotel. }\end{array}$} & Strongly disagree & 0 & 0 & \multirow{5}{*}{4.28} & \multirow{5}{*}{.929} & \multirow{5}{*}{3} \\
\hline & Disagree & 22 & 11.0 & & & \\
\hline & Neutral & 0 & 0 & & & \\
\hline & Agree & 79 & 39.5 & & & \\
\hline & Strongly Agree & 99 & 49.5 & & & \\
\hline \multirow{5}{*}{$\begin{array}{l}\text { AIS leads to Increase } \\
\text { maintenance and repair } \\
\text { costs of assets and } \\
\text { equipment. }\end{array}$} & Strongly disagree & 0 & 0 & \multirow{5}{*}{4.23} & \multirow{5}{*}{.969} & \multirow{5}{*}{5} \\
\hline & Disagree & 22 & 11.0 & & & \\
\hline & Neutral & 10 & 5.0 & & & \\
\hline & Agree & 69 & 34.5 & & & \\
\hline & Strongly Agree & 99 & 49.5 & & & \\
\hline \multirow{5}{*}{$\begin{array}{l}\text { AIS significantly affects the } \\
\text { increased costs of the food } \\
\text { and beverage division }\end{array}$} & Strongly disagree & 0 & 0 & \multirow{5}{*}{4.27} & \multirow{5}{*}{.921} & \multirow{5}{*}{4} \\
\hline & Disagree & 11 & 5.5 & & & \\
\hline & Neutral & 32 & 16.0 & & & \\
\hline & Agree & 50 & 25.0 & & & \\
\hline & Strongly Agree & 107 & 53.5 & & & \\
\hline \multirow{5}{*}{$\begin{array}{l}\text { AIS increases the cost of the } \\
\text { room division. }\end{array}$} & Strongly disagree & 0 & 0 & \multirow{5}{*}{3.33} & \multirow{5}{*}{1.070} & \multirow{5}{*}{9} \\
\hline & Disagree & 63 & 31.5 & & & \\
\hline & Neutral & 38 & 19.0 & & & \\
\hline & Agree & 70 & 35.0 & & & \\
\hline & Strongly Agree & 29 & 14.5 & & & \\
\hline \multirow{5}{*}{$\begin{array}{l}\text { AIS ncreases costs of } \\
\text { entertainment programs. }\end{array}$} & Strongly disagree & 11 & 5.5 & \multirow{5}{*}{3.81} & \multirow{5}{*}{1.034} & \multirow{5}{*}{6} \\
\hline & Disagree & 11 & 5.5 & & & \\
\hline & Neutral & 30 & 15.0 & & & \\
\hline & Agree & 101 & 50.5 & & & \\
\hline & Strongly Agree & 47 & 23.5 & & & \\
\hline \multirow{5}{*}{$\begin{array}{l}\text { AIS leads to increase the } \\
\text { number of employees in the } \\
\text { hotel. }\end{array}$} & Strongly disagree & 0 & 0 & \multirow{5}{*}{3.40} & \multirow{5}{*}{1.139} & \multirow{5}{*}{8} \\
\hline & Disagree & 68 & 34.0 & & & \\
\hline & Neutral & 21 & 10.5 & & & \\
\hline & Agree & 74 & 37.0 & & & \\
\hline & Strongly Agree & 37 & 18.5 & & & \\
\hline AIS helps to reduce the & Strongly disagree & 29 & 14.5 & & & \\
\hline increase of employees' turn & Disagree & 31 & 15.5 & & & \\
\hline & Neutral & 70 & 35.0 & 3.00 & 1.167 & 10 \\
\hline & Agree & 52 & 26.0 & & & \\
\hline & Strongly Agree & 18 & 9.0 & & & \\
\hline AIS reduces the cost of & Strongly disagree & 0 & 0 & & & \\
\hline promotion and marketing & Disagree & 29 & 14.5 & & & \\
\hline advertising. & Neutral & 53 & 26.5 & 3.54 & .856 & 7 \\
\hline & Agree & 99 & 49.5 & & & \\
\hline & Strongly Agree & 19 & 9.5 & & & \\
\hline AIS lead to increase & Strongly disagree & 0 & 0 & & & \\
\hline water costs and an energy & Disagree & 0 & 0 & & & \\
\hline
\end{tabular}


International Journal of Heritage, Tourism and Hospitality Vol. (13), No. (1), March, 2019 By: Faculty of Tourism and Hotels, Fayoum University

\begin{tabular}{|c|c|c|c|c|c|c|}
\hline \multirow[t]{3}{*}{ emental (electricity - fuel). } & Neutral & 0 & 0 & \multirow[t]{3}{*}{4.50} & \multirow[t]{3}{*}{.501} & \multirow[t]{3}{*}{1} \\
\hline & Agree & 101 & 50.5 & & & \\
\hline & Strongly Agree & 99 & 49.5 & & & \\
\hline \multirow{5}{*}{$\begin{array}{l}\text { AIS increases all the } \\
\text { elements of costs inside the } \\
\text { hotel in general. }\end{array}$} & Strongly disagree & 0 & 0 & \multirow{5}{*}{4.33} & \multirow{5}{*}{.744} & \multirow{5}{*}{2} \\
\hline & Disagree & 11 & 5.5 & & & \\
\hline & Neutral & 0 & 0 & & & \\
\hline & Agree & 101 & 50.5 & & & \\
\hline & Strongly Agree & 88 & 44.0 & & & \\
\hline \multicolumn{4}{|c|}{ Average Mean } & 3.87 & ----- & -- \\
\hline
\end{tabular}

Note: $\mathrm{R}=$ Rank, S.D. $=$ Standard Deviation

According to the results shown in the table (10), the respondents agreed on seven statements from all statements on the dimension the impact of the comprehensive accommodation system on the hotel's own costs which are arranged according to their means as follows:

- The statement of "AIS leads to Increased water costs and an energy elemental (electricity - fuel). " has got the highest percentage of agreement from the respondents at (Mean=4.50).

- The statement of "AIS leads to an increase in all the elements of costs inside the hotel in general" at (Mean=4.33). This result has been agreed with the result of Bilgili et al., (2016) that it is only possible for large-scale establishments buying their food, drinks and other needs in total and huge amounts to drop costs being granted a rebate.

- The statement of "AIS causes an increase in the depreciation of assets and equipment in the hotel" at (Mean=4.28).

- The statement of "ASI significantly affects the increased costs of the food and beverage division" at (Mean=4.27). Unguren et al., (2009) similarly argue that food \& beverage waste is extremely high in accommodation enterprises implementing the all-inclusive system.

- The statement of " AIS leads to Increase maintenance and repair costs of assets and equipment" at (Mean=4.23). Ozdemir et al.,(2011) similarly stated that all-inclusive system increases maintenance \& repair costs.

- The statement of "AIS leads to Increased costs of entertainment programs" at (Mean=3.81).

- The statement of "AIS leads to me reduces the cost of promotion and marketing advertising" at $($ Mean=3.54).

Meanwhile, the responses of managers were neutral with three statements from all statements on the dimension the impact of the all-inclusive system on the hotel's own costs which are arranged according to their means as follows:

- The statement of "Lead to Increase the number of employees in the hotel" at (Mean=3.40). Meanwhile, the study by Unguren et al., (2009) asserts that enterprises implementing the AIS in Antalya employ fewer employees than other hotels in the region.

- The statement of "AIS leads to an increase in the cost of the room division" at (Mean=3.33).

- The statement of "AIS helps to reduce the increase in employees' turn over" at (Mean=3.00). In this sense, it should notice that declared that in all-inclusive resorts frontline service employees have been poorly paid and poorly trained with low motivation, causing high job dissatisfaction and high turnover (Upchurch \& Lashley, 2006).

Results in the table (10) clarified that managers agreed with statements of dimension the impact of the all-inclusive system on the hotel's own costs with average mean 3.87. In general, it could notice that, implementing the AIS show that, although the occupancy rate rises, costs also increase and therefore overall profitability is negatively affected (Ozdemir et al., 2011). 


\section{Testing study hypotheses}

In this part, the researcher seeks to explore and analyze the relationships between independent and dependent variable. Before determining the relationship between variables, it should be important to test distribution of data normality to identify the best statistical method either parametric or non-parametric tests.

\section{Test of distribution data normality:}

The aim of this part is to determine if the distribution of data follows parametric or nonparametric tests. This stage is significant in choosing the best tests during the measurement of Relationships between the Variables of the study. Table (10) shows the results

Table 10: Testing the normality of questionnaire dimensions.

\begin{tabular}{|l|c|c|c|c|c|c|c|c|}
\hline \multirow{2}{*}{ Dimensions } & \multicolumn{3}{|c|}{ Kolmogorov-Smirnova } & \multicolumn{3}{c|}{ Shapiro-Wilk } \\
\cline { 2 - 8 } & Statistic & df & sig. & statistic & df & sig. \\
\hline \multirow{2}{*}{ The importance of AIS } & Magers Questionnaire \\
\hline Cost management & .174 & 200 & .000 & .887 & 200 & .000 \\
\hline
\end{tabular}

Significant at $>0.05$.

As it can be observed from the previous table (11) that, the significance of the data is lower than 0.05 , so it could be accept the hypotheses that the study follows non- parametric tests. As regard this result the researcher used Kruskal-Wallis in variance analysis, and Spearman test in the correlation analysis.

\section{All-Inclusive adoption}

Studying the difference among the hotel sample according to the AIS Adoption using Chi-square is important to test the below hypothesis.

H1: There is a significant difference among the hotel sample according to the AIS Adoption.

Table 11: Testing the difference among the hotel sample according to the AIS Adoption.

\begin{tabular}{|l|r|r|r|}
\hline \multicolumn{5}{|c|}{ Chi-Square Tests } \\
\hline & \multicolumn{1}{c|}{ Value } & \multicolumn{1}{c|}{ df } & \multicolumn{1}{c|}{ Asymp. Sig. (2-sided) } \\
\hline Pearson Chi-Square & $50.383^{\mathrm{a}}$ & 12 & .000 \\
\hline Likelihood Ratio & 46.352 & 12 & .000 \\
\hline Linear-by-Linear Association & .854 & 1 & .355 \\
\hline N of Valid Cases & 200 & & \\
\hline
\end{tabular}

a. 9 cells $(45.0 \%)$ have expected count less than 5. The minimum expected count is .60 .

According to the results in the above table (12), it could be concluded that there is a significant level of Chi-square was (50.38), this means there is a significant difference between the sample. The alternative hypothesis is supported according to this value $(0.00)$.

$\mathrm{H} 2$ : There is a significant difference among the hotel sample according to the AIS importance.

Table 12: Testing the difference among the hotel sample according to the AIS importance.

\begin{tabular}{|l|r|r|r|}
\hline \multicolumn{4}{|c|}{ Chi-Square Tests } \\
\hline & Value & df & Asymp. Sig. (2-sided) \\
\hline Pearson Chi-Square & $281.994^{\mathrm{a}}$ & 36 & .000 \\
\hline Likelihood Ratio & 284.050 & 36 & .000 \\
\hline N of Valid Cases & 200 & & \\
\hline
\end{tabular}

a. 37 cells $(74.0 \%)$ have expected count less than 5. The minimum expected count is 1.20. 
According to the results in the above table (13), it could be concluded that there is a significant level of Chi-square was (281.99), this means there is a significant difference between the sample. The alternative hypothesis is supported according to this value $(0.00)$.

\section{Relationship between AIS adoption and hotel profitability}

This section discuss the hypotheses related to the relationship between the all-inclusive system adoption variable and the hotel profitability

H3: There is a significant relationship between the all-inclusive system adoption variable and the hotel profitability:

H3.1: There is a significant relationship between the all-inclusive system adoption variable and the hotel cost management.

H3.2: There is a significant relationship between the all-inclusive system adoption variable and the hotel occupancy rate.

H3.1: There is a significant relationship between the all-inclusive system adoption variable and the hotel cost management.

Table 13: Cost management

\begin{tabular}{|l|r|r|r|r|c|}
\hline \multicolumn{7}{|c|}{ ANOVA } \\
\hline & Sum of Squares & \multicolumn{1}{c|}{ df } & Mean Square & F & Sig. \\
\hline Between Groups & 20.465 & 3 & 6.822 & 28.629 & .000 \\
\hline Within Groups & 46.704 & 196 & .238 & & \\
\hline Total & 67.169 & 199 & & & \\
\hline
\end{tabular}

It is noticed from the above table (14), it could be concluded that there is a significant level of ANOVA was (0.00), this means there is a significant difference between the sample. The alternative hypothesis is supported according to this value $(0.00)$.

H3.2: There is a significant relationship between the all-inclusive system adoption variable and the hotel occupancy rate.

Table 14: Hotel average occupancy

\begin{tabular}{|l|c|r|r|r|c|}
\hline \multicolumn{7}{|c|}{ ANOVA } \\
\hline & Sum of Squares & \multicolumn{1}{c|}{ df } & Mean Square & \multicolumn{1}{c|}{ F } & \multicolumn{1}{c|}{ Sig. } \\
\hline Between Groups & .012 & 1 & .012 & 2.07 & .152 \\
& & & & 1 & \\
\hline Within Groups & 1.140 & 197 & .006 & & \\
\hline Total & 1.152 & 198 & & & \\
\hline
\end{tabular}

It is noticed from the above table (15), it could be concluded that there is no significant level of ANOVA was (0.152), this means there is no significant difference between the sample. The alternative hypothesis is not supported according to this value $(0.152)$.

\section{Recommendations}

Based upon both the literature reviewed and the field study findings, recommendations could be divided toward two aspects as follows:

\section{Hotels' general managers:}

1. Setting SWOT Analysis (strength, opportunities, weakness, threats) of applying the allinclusive system before implementation.

2. Conducting continuous reports reveals to hotel's performance and profitability through applying the all-inclusive system. 
3. Analyzing types of the all-inclusive system and choosing the best system that suitable with hotel abilities and assets.

4. Taking maintenance importance in consideration during applying all-inclusive system due to its negative impact on hotel assets

5. It should create various marketing issues to attract the most number of the market slice.

6. Contracting with travel and tourism companies that specialized in organizing all-inclusive tours.

7. Increasin the awareness of guests about how they use and entertain with hotels' facilities without leaving a negative effect from their accommodation after departure.

\section{Hotels' departments' managers:}

1. Managers in each department should conduct training and orientation lessons to their employees in order to maintain on hotel assets and equipmet.

2. F\&B managers should evaluate the average of guest's usage and consumption to reduce the waste of food and beverage.

3. It supposed to train hotel staff on work achievement under the all-inclusive system

4. Setting a controlling system that contributesto waste management and reduces the all-inclusive system problems

5. Counting the cost of provided facilities in all areas and compared it with profitability.

6. Creating facilities that maximize the hotel's profitability and increase guest satisfaction.

Recommendations to the Ministry of Tourism:

1- The Ministry of Tourism, represented in the hotel facilities room, should make a political decision for pricing the programs for the type of flights and hotels that operate under the allinclusive system.

2- There should be a tangible role for the customer protection system to prevent monopoly.

3- The Egyptian Federation of Tourist Chambers should play an important role in the policy of prices, in light of the fierce competition between tourism companies, tour operators and hotels that operate with the all-inclusive system.

4- Hotels with the all-inclusive system must do the recycling for food and beverages.

\section{Recommendations for further research}

All-inclusive system has become an important one in the hotel's industry. Therefore, studying the all-inclusive system dimension is very significant. This study was designed to determine the effect of an all-inclusive system on the profitability of Hurghada five-star hotels.

It could be recommended for further researches to investigate other effects of all-inclusive system in other aspects such as" the effect of an all-inclusive system on employees performance", or focusing on specific hotel department such as food and beverage department as a case study. It could be also applying this study on another degree of the hotel such as four or three-starihotels.

\section{References}

Abdel Wahab, S. (1996) Tourism in a changeable world. Cairo: Helal establishment.

Abdou, D. S. and Zaazou, Z. (2013) 'The Egyptian revolution and post socio-economic impact', Topics in Middle Eastern and African Economies, 15(1), pp. 92-105.

Ben Aissa, S. and Goaied, M. (2016) 'Determinants of Tunisian hotel profitability: The role of managerial efficiency', Tourism Management, 52, pp. 478-487. doi: 10.1016/j.tourman.2015.07.015. 
Assaf, A. and Cvelbar, L. K. (2010) 'The performance of the Slovenian hotel industry', Tourism Economics, 10(2), pp. 177-192.

Banker, R. D., Potter, G. and Srinivasan, D. (2005) 'Association of nonfinancial performance measures with the financial performance of a lodging chain', Hotel and Restaurant Administration Quarterly, 46(4), pp. 394-412.

Barros, C. P. and Mascarenhas, M. J. (2005) 'Technical and allocative efficiency in a chain of small hotels', International Journal of Hospitality Management, 24(3), pp. 415-436.

Bazazo, I. (2010) 'Evaluating the using of comprehensive quality administration in hotels', .Journal of human sciences, 5, pp. 156-177.

Bilgili, B., Özkul, E. and Candan, B. (2016) 'An Outlook on "all Inclusive" System as a Product Diversification Strategy in Terms of Consumer Attitudes', Procedia - Social and Behavioral Sciences, 235, pp. 493-504. doi: https://doi.org/10.1016/j.sbspro.2016.11.060.

Celebi, E., Kahraman, S. A. and Daugli, Y. (2004) Evliya Çelebi Travelogue with Contemporary Turkism: Bursa-Bolu-Trabzon-Erzurum-Azerbaijan-Caucasus. YKY.

Chen, H. M. and Tseng, C. H. (2005) 'The performance of marketing alliances between the tourism industry and credit card issuing banks in Taiwan', Tourism Management, 26(1), pp. 15-24.

Chen, T. H. (2009) 'Performance measurement of an enterprise and business units with an application to a Taiwanese hotel chain', International Journal of Hospitality Management, 28(3), pp. 415-422.

Ciftci, H., Duzakin, E. and Onal, Y. B. (2007) 'All inclusive system and its effects on the Turkish tourism sector', Problems and Perspectives in Management, 5(3), pp. 269-285.

Claver, E., Andreu, R. and Quer, D. (2006) 'Growth strategies in the Spanish hotel sector: determining factors', International Journal of Contemporary Hospitality Management, 18(3), pp. 188-205.

Condratov, I. (2014) 'All inclusive system adoption within romanian tourist sector', Ecoforum Journal, 3(1), pp. 78-83.

Demir, F. Ö. (2004) Analysis of the Effects of the All-Inclusive Price System on the Cost and Profitability of Tourism Enterprises. Master Thesis, Akdeniz University.

Demir, M. and Demir, S. (2001) 'Analysis of All-Inclusive Pension Type Application for Hospitality Enterprises, Personnel, Customers, Travel Agencies and Other Independent Companies in the Region', Maltepe Üniversitesi Meslek Yüksekokulu Dergisi, 1, pp. 67100.

Dix, C. and Baird, C. (1992) Front Office Operations. Pitman, London.

Egyptian Hotel Association (2018). Available at: http://www.egyptianhotels.org/Hotels.aspx?id=HURGHADA.

Egyptian Hotel Association (EHA) (2018).

Emam, H. (2012) Studying Customers and Staff Perception towards All-inclusive Programs in Resort Hotels. Unpublished PhD thesis, Faculty of Tourism and Hotels, Hotel Managment, Helwan University.

Graves, C. and Shan, Y. G. (2014) 'An empirical analysis of the effect of internationalization on the performance of unlisted family and nonfamily firms in Australia', Family Business Review, 27(2), pp. 142-160.

Hair, J. F. et al. (1995) Multivariate Data Analysis. New Jersey: Prentice-Hall International Inc.

Issa, J. \& Jayawardena, C. (2003) 'The "all-inclusive" concept in the Caribbean', International Journal of Contemporary Hospitality Management, 15(3), p. 167.171. 
Kim, W. G., Cho, M. and Robert, A. B. (2013) 'Determinants affecting comprehensive propertylevel hotel performance: the moderating role of hotel type', International Journal of Hospitality Management, 34, pp. 404-412.

Krasnoperova V., Shchetkina A., Martyn D., G. E. (2016) the Role of the Hotel Industry in the World Economy, Экономика и социум. Available at: www.iupr.ru.

Lee, S. (2008) 'Internationalization of US multinational hotel companies: expansion to Asia versus Europe', International Journal of Hospitality Management, 28(1), pp. 105-112.

Lee, S. et al. (2014) 'A synergy effect of internationalization and firm size on performance: US hotel industry', International Journal of Contemporary Hospitality Management, 26(1), pp. $35-49$.

Muijs, D. (2010) Doing Quantitative Research in Education with SPSS. SAGE Publications. Available at: https://books.google.com.eg/books?id=apFMQHF768EC.

Mutisya, M. M. (2010) 'The All-Inclusive Holiday Concept at the Kenyan coast', International Research Symposium in Service Management, (August), pp. 24-27.

Onal, Y., Duzakin, E. and Ciftci, H. (2007) "'All Inclusive System and Its Effects on the Turkish Tourism Sector"', Journal of Problems and Perspectives in Management, 5(3), pp. 269281.

Ozdemir, A. et al. (2011) 'Effects of the all-inclusive system (AIS) on the financial structure of accommodation enterprises in Antalya', European Journal of Social Sciences, 24(4), pp. 503-515. Available at: https://www.scopus.com/inward/record.uri?eid=2-s2.080054741183\&partnerID=40\&md5=7a5aa394faee05bc2cb4355f9e8fe369.

Parte-Esteban, L. and Ferrer Garcia, F. (2014) 'The influence of firm characteristics on earnings quality', International Journal of Hospitality Managemen, 42(September), pp. 50-60.

Pelit, E. et al. (2011) 'Tourism Academicians' Assesment on Advantages and Disadvantages of All-Inclusive System Applied on Turkish Tourism Sector', Management and Education, 4(3), pp. 210-214.

Perrigot, R., Cliquet, G. and Piot-Lepetit, I. (2009) 'Plural form chain and efficiency: insights from the French hotel chains and the DEA methodology', European Management Journal, 27(4), pp. 268-280.

Pine, R. and Phillips, P. A. (2005) 'Performance comparisons of hotels in China', International Journal of Hospitality Management, 24(1), pp. 57-73.

Reinhold, V. (1997) The Travel Industry. Third edit. A Division of International Thomoson, Inc, New York.

Richard, B. and Cleveland, S. (2016) 'The future of hotel chains: Branded marketplaces driven by the sharing economy', Journal of Vacation Marketing, 22(3), pp. 239-248. doi: $10.1177 / 1356766715623827$.

Rouby, Aln. (1986) 'Tourism theory', in Group cultural establishment. Alexandria, p. 13.

Saleh, L., Esam, H. and Elias, A. N. (2013) 'Customers and staff perception towards Allinclusive Programs in Resort Hotels', Journal of Faculty of Tourism and Hotels, Fayoum University, 7(2), pp. 46-63.

Santoro, G. (2015) 'Evaluating performance in the hotel industry: an empirical analysis of piedmont', Journal of Investment and Management, 4(1), pp. 17-22.

Sun, S. and Lu, W. (2005) 'Evaluating the performance of the taiwanese hotel industry using a weight slacks-based measure', Asia-Pacific Journal of Operational Research, 22(4), pp. 487-512.

Swarbrooke, J. and Horner, S. (1999) Consumer Behavior in Tourism. Butterworth-Heinemann, 
Linacre House.

Tang, C. H. and Jang, S. (2009) 'The tourism-economy causality in the United States: a Subindustry level examination', Tourism Management, 30(4), pp. 553-558.

Tavares, J. M. and Kozak, M. (2015) 'Tourists' Preferences for the All-Inclusive System and Its Impacts on the Local Economy', European Journal of Tourism, Hospitality and Recreation, 6(2), pp. 7-23.

Turner, M. J. and Guilding, C. (2011) 'An investigation of the motivation of hotel owners and operators to engage in earnings management', Qualitative Research in Accounting and Management, 8(4), pp. 358-381.

Upchurch, R. and Lashley, C. (2006) Timeshares Resort Operations: A Guide to Management Practice. Elseveier Inc, Oxford.

Wielenga, B. and Postma, A. (2015) 'Ethical issues of all inclusive tourism', European Tourism Futures Institute.

World Economic Forum (WEF) (2015). The travel and tourism competitiveness report 2015. Geneva, ISBN-13: 978-92- 95044-48-7. (no date).

Xiao, Q., O'Neill, J. W. and Mattila, A. S. (2012) 'The role of hotel owners: the influence of corporate strategies on hotel performance', ", International Journal of Contemporary Hospitality Management, 24(1), pp. 122-139.

Yang, Y., Luo, H. and Law, R. (2014) 'Theoretical, empirical, and operational models in hotel location research', International Journal of Hospitality Management, 36(1), pp. 209-220.

Zahra, I. (2012) 'Destination image and tourism: A case study of Bangladesh', European Journal of Business and Management, 4(6), pp. 18-27. Available at: http://www.iiste.org/Journals/index.php/EJBM/article/view/1574. 